\title{
Reducing of the Acquisition Costs for Products
}

\author{
Jozef Mihok* \\ Slovak Office of standards, metrology and testing, Bratislava, Slovak republic
}

\section{BIOGRAPHICAL NOTES}

Dr. h. c. prof. Ing. Jozef Mihok, PhD. (born in 1950) received the Ing. and PhD. degrees from Faculty of mechanical engineering of Technical university Košice. In the year 2008 he was appointed as the Professor in the industrial engineering field of study. He is currently President of Slovak Office of standards, metrology and testing in Bratislava. His research interests include industrial engineering and crisis management.

\section{KEY WORDS}

Acquisition costs, parameter, optimization.

\section{ABSTRACT}

The acquisition costs are the total costs for a firm to buy an assets. The acquisition cost includes all legal fees, closing costs, or other increases. Presented article is aimed at parametrical description of acquisition costs mainly in logistics.

\section{Introduction}

The acquisition costs which are bound to the final product represent not a small item. Therefore it is necessary to pay attention to this issue, thus seek to optimize the total costs of the product. In this context, it is essential to adequately determine the level of value provided to a customer (Figure 1) by the company.

It is also useful to review the product in terms of those parameters that generate the desired level of a customer and eliminate the following:

Insufficient parameters of the product lead to:

- losses during the usage - failure rate - higher costs for installation, operation, maintenance,

- a higher personal demand - the identification and subsequent resolution of the problem - the need to use own labour - operators, technicians, managers,

Inapplicable parameters of the product lead to:

- losses at the moment of acquisition - maximizing of prices - additional requirements on the product both objective - compatibility with the "new" and both subjective envy,

- the unplanned costs in the future - resulting from a lack of conceptual work in the field of investment and technology development,

Determination of value level for a customer in a mutual comparison of competetive bids can be then used for setting goals in preparation for the purchase negotiations.

The total costs associated with materials management can be examined in the following basic structure [1]:

Relative consumption per unit of production expressed in value units (physical units multiplied by a price per a piece).

- Consumption of material is mainly influenced by the structure of the final product, in 


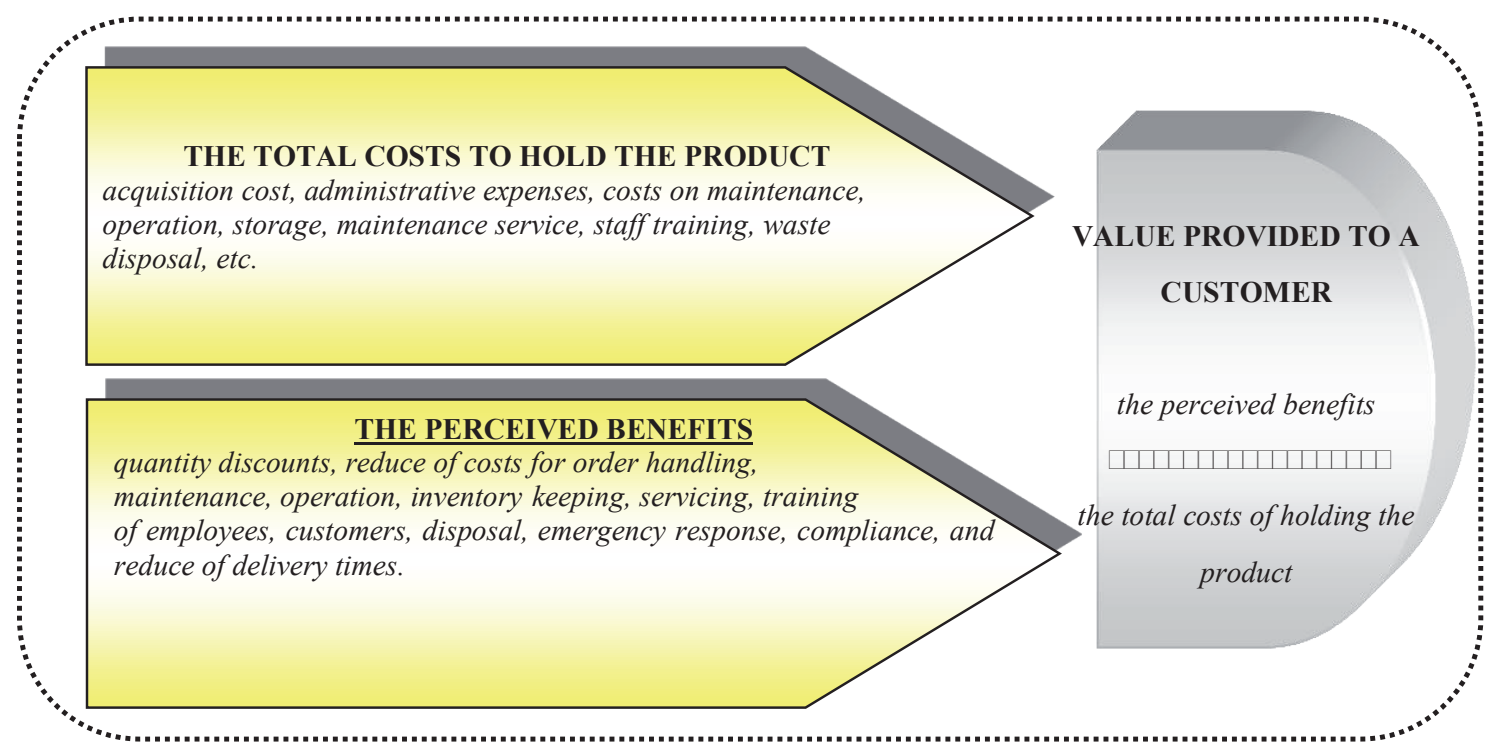

Fig. 1: Value provided to a customer

which specifies the type of material, shape, weight, dimensions of the parts forming the final product.

- Another important factor affecting the consumption of material is a suitable choice of processing technology, that is:

- selection of a technological process, which predetermines the degree of material utilization socalled utility consumption, and it also tries to comply with technological procedures,

- selection of a semi-finished product - a sort of standardized semi-finished product - a metal sheet, the length of rods, profiles, which determines the amount of waste and loss

- selection of production equipment and tools, which affects the degree of materials utilization, waste characteristics - shape, size, purity, and thus the degree of reuse,

- consumption of auxiliary materials, products, energy, and so on.

- Price of material is another factor which is counted into the cost and ultimately forms a part of the final product prices. Price of inputs depends mainly on the type and quality of material used, therefore it is necessary to choose such material standard that complies with the technical and economic criteria of production and sales. The price can be influenced by, for example:

- the appropriate timing of the purchase - the use of temporary or seasonal price reductions,

- purchasing of the optimal amount - obtaining of quantity discount (not at the expense of high costs associated with storage in relation to pre-stocking), - expanding of the suppliers portfolio - reduce respectively purchasing distribution of risk, achieve a better market position compared to the supplier.

Transportation and other costs associated with the order

- These costs depend primarily on the size of the delivery, a distance of suppliers, a type of transport and on the one who bears the costs of transportation, a method of packaging, range handling of purchased materials and semi-finished products. These costs can be optimized of course and so by:

- a quality of planning, respectively forecasting the future needs of material inputs - by their absence, the costs of repeated providing of inputs rise and by excess such costs as the cost of storage, han dling, disposal of unwanted, damaged, outgoing inventory increase,

- selecting the optimal size of the delivery - is determined by the delivery-cycle, the extent of manipulation,

- an appropriate choice of a supplier - it predetermines the distance that must be overcome to ensure the material inputs and it also predetermines the type of transport, packaging methods.

\section{Storage and handling costs}

These costs are mainly influenced by:

- a storage range - the quality of inventory management as that predetermines an amount of the 
stock in the warehouse,

- a technical level of the storage and handling equipment and storage technology - with that are associated the following - capital costs, depreciation, payload, energy consumption,

- a level of organization and managing of the warehouse - inventory record-keeping, movement and activities that are the responsibility of the warehousemen, qualification of warehousemen.

\section{The cost of the supply unit}

These costs primary depend on the level of qualification and skills of employees, software which provides information processing concerning material management, and on the level of communication and cooperation between different departments of the company, or on the level of supplier-customer relationships.

\section{Determination of the Economic Size of the Delivery}

When determining the size of an order it is possible to proceed:

- intuitively when it comes to an expert's estimate, - by an estimate of the order by comparing needs with previous periods,

- by a conversion of an optimal amount of the order, so-called Harris - Willson formula.

Economic ordering quantity is the level of inventory that minimizes the costs of its holding and ordering. F. W. Harris defined compact methodology for calculating the mentioned metrics already in 1913.

The aim is to determine such a quantity that meets the minimum of total cost associated with ordering and storage. Lower order quantity increases the number of orders and so ordering costs, and higher order quantity increases storage costs.

It is useful to formulate the conditions under which the model can be used:

- Ordering cycle is constant demand for storage of goods and it is approximately linear in time.

- Cost and price of purchased material are constant: the cost to proceed a single order, cost of storage including bonding of capital stock are known.

- Time of realization is constant: the stock is replenished periodically in equal sizes as the optimal size of orders.

-Delivery is complete: overall demand for ordered goods in the monitored period is known - it is therefore completely determined consumption, quantity ordered is available when needed.

The formulation of the model assumes a linear consumption of formed supply in the monitored period, while it does not consider safety reserve, which means that the minimum stock equals zero and the maximum stock is equal to the size of the order.

Statements for the total annual variable costs of supply of the specific item consist of several steps[5]:

- it is necessary to determine the section of the acquisition annual costs, which is dependent on the number of orders per year. The number of orders is represented as a ratio of the total annual demand and the order quantity. (Multiplied by the variable costs of procurement per order),

- annual storage cost - based on the size of the average level of inventory so that is half of the maximum and minimum levels of inventory (which simplifies the calculation).

- the cost of goods is included in here as well.

The use of the differential calculus - derivative of the function of one variable is closely related to the local minimum of the total cost function. Economic order quantity / EOQ is defined at the point where the function reaches the local extreme and optimizes the minimum ordering quantity. This is the point at which the function's full cost is minimal (at this point, the cost of acquisition and stock holding are equal).

The full cost can be expressed as the sum of the total costs, expressed in the total cost of purchased items, the full ordering cost and the full inventory holding cost (finances bound in stocks plus costs associated with the storage and handling), Table 1 [2.3]

\section{The total cost of acquisition and inventory holding = Costs associated with a price + Order costs + Inventory holding costs}

The above relations are calculated with a fixed unit purchase price. The order is often done in volume which reflects discounts for quantity purchased, thus for purchasing of larger quantity can be given discounts by a supplier. It is therefore necessary to decide whether it is preferable to purchase the optimal amount for the basic price per piece, or to consider a higher volume of inputs purchased at a discount from the price (as it is the 
Table 1: The costs associated with acquisition and inventory holding

\begin{tabular}{|c|c|}
\hline \multicolumn{2}{|l|}{ Monitored index figure } \\
\hline $\begin{array}{l}\text { COSTS ASSOCIATED WITH PRICE } \\
\mathrm{N}_{c}=\mathrm{P} \times \mathrm{D}\end{array}$ & $\begin{array}{l}\text { the total annual cost of purchasing material inputs company needs to meet the demand for } \\
\text { that item }\end{array}$ \\
\hline $\begin{array}{l}\text { ORDERING COSTS } \\
\mathrm{N}_{0}=\mathrm{C} \times \mathrm{D} / \mathrm{Q}\end{array}$ & $\begin{array}{l}\text { he cost of ordering company's material inputs, and with each ordering there are fixed costs } \\
\text { associated C (e.g. transport costs) and the volume of the order is expressed as follows } D / Q \text {, } \\
\text { where } D \text { is the annual demand and } Q \text { is the quantity in one order }\end{array}$ \\
\hline $\begin{array}{l}\text { HOLDING COSTS } \\
\mathrm{N}_{\text {skl }}=\mathrm{H} \times 0 / 2\end{array}$ & $\begin{array}{l}\text { it represents the average of the stocks that are in the warehouse at the time of the supplies } \\
\text { arrival of inputs. Ideally it is the average between the point of delivery when the stock } \\
\text { "climbs" to its maximum and thus } Q \text { and between the point before the next delivery when } \\
\text { stocks are at } 0 \text { (since it does not consider the safety reserve). Then these costs can be } \\
\text { expressed as } Q / 2\end{array}$ \\
\hline THE TOTAL COSTS ASSOCIATED V & $\underset{\mathrm{Q}_{\text {optimal }}}{\stackrel{\text { ordering costs }}{\longrightarrow}}$ \\
\hline \multicolumn{2}{|c|}{ To find the local extreme (in this case minimum) it is required to derivate functions of the full cost (by DQ), it equals to zero: } \\
\hline \multicolumn{2}{|r|}{$\frac{d T C(Q)}{d Q}=\frac{d}{d Q}\left(P D+\frac{C D}{Q}+\frac{H Q}{2}\right)=0 \Rightarrow-\frac{C D}{Q^{2}}+\frac{H}{2}=0$} \\
\hline \multicolumn{2}{|c|}{$\begin{array}{l}\text { After expressing } \mathrm{Q} \text { it is } \mathrm{Q} \text { *obtained, which represents the optimal order quantity: } \\
\qquad Q^{*}=\sqrt{\frac{2 C D}{H}}\end{array}$} \\
\hline \multicolumn{2}{|c|}{$\begin{array}{l}\text { Key: } \\
T C=\text { total cost } \\
Q=\text { order quantity (pieces) } \\
Q^{*}=\text { optimal order quantity }(p c) \\
D=\text { annual demand for a product expressed in pieces }(p c) \\
P=\text { price of one piece (Euro/pc) } \\
C=\text { fixed cost of an order (Euro) } \\
H=\text { annual inventory holding cost expressed in pieces (Euro/pc) }\end{array}$} \\
\hline
\end{tabular}

optimal order size). Purchasing at a discount would be favourable provided that the amount of the discount is higher than the costs that are associated with the storage of large quantities of purchased inputs.

Therefore it is appropriate to consider the pros and cons of purchasing in small and large quantities compared to determinate amount of the order representing optimum. Smaller order quantity increases the number of orders and ordering costs, higher order quantity increases the storage costs.
Advantages and disadvantages of purchasing in large and small quantities are listed below[6]

\section{Purchasing in a large amount}

- advantages: a quantity discount, which can be used as a competitive advantage (lower prices of final products, providing of discounts, etc.); lower administrative and transportation costs in connection with fewer orders; the lower risk of goods out of stock before the arrival of the next order; the lower risk at increase of the purchase price in the future, 
- disadvantages: financial costs and long capital bond; the risk of insolvency; increased storage costs; insurance costs; interests in buying on credit; an increased risk of deterioration and loss during storage.

\section{Purchasing in a small amount, so-called "from hand to mouth"}

advantages: more accurate estimation of material requirements; lower capital bond; lower risk of deterioration and loss; lower storage and insurance costs[4].

- disadvantages: the risk of supply shortage; no discount utilization; higher transport costs and constant supplies may increase costs associated with revenue items in stock.

It often leads to a situation that the price of ordered items depends on ordered quantity in determining the size of the order. Character of price degression often may be:

1. if the order exceeds a certain quantity limit then the favourable price for all ordered items is obtained - price degression of the 1st type,

2. lower price refers to the units of quantity that exceed a certain volume - price degression of the 2nd type.

\section{Conclusion}

In conclusion, this paper was aimed at reduction of acquisition costs. A number of optimization models based on different criteria for inventory and warehouse management was developed. The following factors contribute to the modifications of basic models- quantity discounts, order quantity (handling units), ordering of several items from one supplier, the limited storage capacity, limited financial resources.

\section{Acknowledge}

This article was created by implementation of the grant project KEGA 004TUKE-4/2013 Intensification of modelling in teaching II. and III. degree in the field of study 5.2.52 Industrial Engineering.

\section{Conflict of Interest}

The authors declare no conflict of interest.

\section{References}

[1] Фоминых Р.Л., Коршунов А.И., Якимович Б.А.Оценка трудоемкости машиностроительного изделия и организационно-технического уровня производства.Экономика и производство №4 (37) октябрь-ноябрь 2003 - c.43.

[2] FIL'O, M. et al.:PLM systems and Tecnomatix Plant Simulation, a description of the environment, control elements, creation simulations and models, In: American Journal of Mechanical Engineering. Vol. 1, no. 7 (2013), p. 165-168. - ISSN 2328-4102

[3] SCHULTE, Ch.: Logistika, Victoria publishing, Praha, 1994

[4] STRAKA, M., MIKUŠOVÁ, Z., LENORT, R.: Analysis and assessment of warehouse stock, In: Hutnické listy. Vol. 66, no. 3 (2013), p. 44-48. - ISSN 0018-8069

[5] FIL'O, M., PEKARČIKOVÁ, M.: Contribution to the creation of the model warehouse management in the company, In: Manažment podnikov. Roč. 3, č. 2 (2013), s. 6264. - ISSN 1338-4104

[6] ROSOVÁ, A., BALOG, M.:. Specifikace logistických nákladů, In: Logistika v praxi. čast 14.5.4.4. srpen (2007), 6 p. - ISSN 1801-8009 